\title{
The Effect of Somatotype Profiles of Adolescent Basketball Players on Biomotoric Characteristics and Ability
}

\author{
UMUT CANLI \\ Ministry of Education, Corlu/Tekirdag-TURKEY
}

\begin{abstract}
In this study, it is aimed to determine the relation between somatotype profiles of basketball players age range of 12-14 with the biomotoric characteristics and abilities particular to basketball. Attendants are 41 basketball players whose average age is 13,07, who are exercising regularly and playing basketball in infrastructure local leagues. Some measurements are performed on attendants such as the body height, the body weight, vertical jump, 1 mile run-walk, aerobic power, anaerobic power, skinfold thickness measurements (triceps, subscapula, suprailiac, calf), circumference measurements (biceps flexion, calf), diameter measurements (humerus bicondular, femur bicondular). While their somatotype characteristics are determined as per Health-Carter method; their abilities particular to basketball are determined by using Harrison Basketball Ability Test (Kamar, 2008). Kolmogorov-Smirnov and Shapiro-Wilk Tests are applied so as to determine whether the data is suitable for normal distribution. Distributions of all tests comply with the normal distributions for both two tests. Pearson correlation cofactor is used so as to determine the relation between varieties. With the endomorphic measurement values; a positive-directional relation is detected between 1 mile run-walk and the body weight values and a negative-directional relation between vertical jump, aerobic power and ability values $(p<, 05)$. With the endomorphic measurement values; a positive-directional relation is detected between 1 mile run-walk and body weight varieties and a negative-directional relation between aerobic power and ability values $(p<, 05)$. With the ectomorphic measurement values; a positive-directional relation is detected between aerobic power and ability and a negative-directional relation between 1 mile run-walk, vertical jump and anaerobic power values $(p<, 05)$. As a result, an increase is observed in aerobic power and abilities particular to basketball of adolescent basketball players who have ectomorphic characteristics.
\end{abstract}

Keywords: Somatotype, Biomotoric, Ability, Basketball.

\section{Introduction}

Today, athletes in all sports branches must be faster and more skilled and have superior anthropometric and physiological characteristics (Ersöz et al., 1996). When we look at the countries and teams that have achieved high level of success in sports branches, it draws attention the fact that people are more informed and studies carried out in the light of more scientifically prepared programs (Gökdemir et al., 1999).

In countries that have achieved international success in sport, scientific studies in universities and similar research institutions play an important role in these achievements. In these studies, the factors that affect performance and the changes that these factors make in the organism are identified and the most appropriate conditions are determined to maximize sportive success. As a result of the fact that the age at which children begin playing sports have decreased, a very important issue such as the early detection of human models that match the characteristics of sports branches has emerged. For those who were initially directed to inappropriate sports, all scientific efforts spent on improving their performance in the elderly are insufficient (Gürses and Olgun, 1978)

Body shape and bodily functions are the leading factors in order to achieve high-level sports performance (Fox et al., 2012). In many sports branches, body shape is often used to determine whether an athlete is appropriate for a particular sports branch. Anthropometric measurements and somatotype have become important in determining skills from the first studies until today. The ideal body composition and the ideal somatotype are an important function of any sports branch (Hopper, 1997).

In many countries, scientists try to reveal athlete profiles according to sports branches in their own countries via their own studies and provide data to give direction to studies of other countries. Although studies have been performed to determine the morphological profiles of athletes in many sports branches in our country and in the world, the obtained data are not sufficient (Muratl1, 1997).

Basketball is one of sports branches that are becoming increasingly widespread in our country and have many fans. In particular, as a result of the fact that our national team and club teams have achieved success in recent years, basketball has taken its place among the popular sports by increasing its fan base. It is necessary that all of the basic motor skills such as strength, speed, endurance, reaction, mobility, skill and coordination are all together in basketball. The fact that the athlete has these basic motoric skills is provided by that the athlete's morphological and physiological structure is suitable with this sports branch (Kılıç et al., 2000). Major 
developments in all sports branches are a product of the evaluation of athletes' basic and specific anthropometric and kinesiological characteristics (Heimer et al., 1988).

In our study, we aimed to determine the effect of somatotype characteristics, which have been determined with the help of anthropometric measures in 12-14-year-old male basketball players, on biomotoric properties and basketball-specific skills.

\section{Methods}

\section{Research group}

This study contains 41 male athletes (with a mean age of 13.07 years, a mean athletic age of 32.6 months and a mean weekly training frequency of 2.8 days) who play basketball in the infrastructure leagues under the Trakya Gucu Sport Club.

\section{Data collection}

The Body Height and The Body Weight Measurements The body height was measured using a wall mounted stadiometer (Brand name: F. Bosch FB 200) with a degree of accuracy of $0.1 \mathrm{~cm}$. The measurements were taken when the feet were naked, the body weights were distributed equally to two legs, the heels united and touched the stadiometer, the head was positioned in the Frankfurt plane and the arms were freely suspended on the side of the shoulder. The body weight was measured using an electronic scale (Brand name: Omron BF511) with a degree of accuracy of $0.1 \mathrm{~kg}$ with only shorts and t-shirts in bare feet. The values obtained were recorded in $\mathrm{kg}$ (Özer, 2009).

\section{Circumference Measurements}

Before circumference measurements were made, the anatomical regions to be measured were determined meticulously. Circumference measurements were taken perpendicular to the long axis of the body or parts. The measurements were made using gullick strip and the skin should not be depressed by squeezing during the measurements (Tamer, 2000). Two measurements were made in each participant and their mean values were taken. If the difference between these two measurements was greater than $7 \mathrm{~mm}$, the test was repeated (Koz, t.y). Calf and flexed biceps circumferences were measured in the participants.

\section{Diameter Measurements}

A slide caliper (Brand name: Holtain) which was previously calibrated was used in diameter measurements. Before the measurement was made, the points to be measured were determined by fingers. The tip of the slide caliper was used to apply as much pressure as possible to the soft tissue and so the measurement result was achieved to be more reliable (Tamer, 2000). Each measurement was taken twice. Humeral and femoral head diameters were measured in the participants.

\section{Skinfold Thickness Measurements}

A skinfold caliper (Brand name: Holtain) was used to provide $10 \mathrm{~g} / \mathrm{sq} \mathrm{m}$ pressure at each angle in skinfold thickness measurements. Skinfold thickness measurements were taken from the right side of the body. The folding process was done so that there was no muscle tissue behind the skin folded with the head and index finger. The caliper was placed $1 \mathrm{~cm}$ away from the area folded with the fingers and the measurements were read and recorded between 2-4 seconds without loosing the fingers holding the skin. Each measurement was repeated twice. Triceps, subscapular, suprailiac and medial calf skin fold thicknesses were measured in the participants.

\section{Somatotype Assessment}

The somatotype values of the participants were determined by the Heath-Carter somatotype method. According to this method, the somatotype values of the participants were determined using the weight and height measurements, calf and flexed biceps circumferences, humeral and femoral head diameters as well as triceps, subscapular, suprailiac and medial calf skin fold thicknesses (Ross and Marfell-Jones, 1991).

\section{Vertical jump test}

For the test, a white board with a length of $200 \mathrm{~cm}$ and a width of $60 \mathrm{~cm}$ was mounted on the wall at a height of $155 \mathrm{~cm}$ from the floor. A deleteable pen was used to record grades. The participant was first asked to touch the highest point where he could stretch his arm in the standing position, then touch the highest point where he could reach by leaping. The distance between the highest point where he could stretch his arm in the standing position and the highest point where he could reach by leaping was measured in $\mathrm{cm}$. This test was repeated three times with listening intervals and the best degree was recorded as score. Before the begining of the test, the participants did warming and stretching movements (Kamar, 2008). 
1 mile run-walk test

The starting and ending points of 1609 metrics in the stadium were determined by the funnels. A Casio handheld clock with a degree of accuracy of 1/1000 is used for the test. The participants started running in groups of five with the command 'Start'. The participants were asked to run the entire distance but were allowed to walk if they could not finish by 1 mile. However, the participants were motivated continuously orally in order to run and adjust running speeds because the goal is to complete the distance as soon as possible. The test result was recorded in the measurement form in minutes and seconds (Özer, 2015).

\section{Aerobic Power (MaxVO2) Measurement}

Maximal oxygen consumption (MaxVO2) was calculated using the following formula according to the result of 1 mile run-walk test.

MaxVO2 $(\mathrm{ml} / \mathrm{kg} / \mathrm{min})=100.5+(8.344 *$ Gender $)-(0.1636 *$ Weight $)-(1.438 *$ Time $)-(0.1928 *$ Heart rate $)$ While a ' 1 ' value is placed on the formula for male participants, a ' 0 ' value is placed on the formula for female participants (George et al., 1993).

Anaerobic Power Measurement

The anaerobic power was measured using the vertical jump test and by placing the values into position in the following formula (Fox et al.,2012).

$\mathrm{P}(\mathrm{kg}-\mathrm{m} / \mathrm{sec})=\sqrt{ } 4.9($ Weight $) . \sqrt{ }$ Vertical jump distance

\section{Harrison Basketball Test}

Harrison has developed a four-item basketball test for boys aged 12-14. These four items consist of scoring, passing, dribbling and rebounding. The duration of application of each item is 30 seconds. At the end of the two attempts given during the test, the highest score was recorded (Kamar, 2008).

\section{Statistical analysis}

We calculated frequency distributions, arithmetic averages, standard deviations, median values, minimum and maximum values of the data obtained from the athletes to provide information about the athletes participating in the study. The Kolmogorov-Smirnov and Shapiro-Wilk Tests were applied to determine whether the data were appropriate for normal distribution. All variables showed a normal distribution for both tests. Normality tests and other statistical analyzes were performed at a significance level of 0.05 . Pearson correlation coefficient was used to measure the relations between variables.

\section{Results}

Table 1. Anthropometric, Biomotoric and Somatotype Features of Adolescent Basketball Players

\begin{tabular}{|l|c|c|c|}
\hline Variables & $\mathrm{n}$ & Arithmetic $\mathrm{m}$. & Sd. \\
\hline Age (year) & 41 & 13.07 & 0,8182 \\
\hline Athletic age (month) & 41 & 32,6098 & 16,9468 \\
\hline Weekly average training (day) & 41 & 2,8293 & 0,6764 \\
\hline The body lenght $(\mathrm{cm})$ & 41 & 158,1098 & 11,7520 \\
\hline The body weight $(\mathrm{kg})$ & 41 & 55,4732 & 14,5398 \\
\hline Vertical jump $(\mathrm{cm})$ & 41 & 32,0976 & 8,9297 \\
\hline 1 mile run-walk $(\mathrm{min})$ & 41 & 7,7317 & 1,66979 \\
\hline Anaerobic power $(\mathrm{kg} \cdot \mathrm{m} / \mathrm{sec})$ & 41 & 70,6778 & 18,8110 \\
\hline Aerobic power $(\mathrm{ml} / \mathrm{kg} / \mathrm{min})$ & 41 & 51,3470 & 5,3947 \\
\hline Endomorphy & 41 & 4,6049 & 2,1592 \\
\hline Mesomorphy & 41 & 4,5732 & 1,4747 \\
\hline Ectomorphy & 41 & 2,2317 & 1,5937 \\
\hline Harrisson basketball test (score) & 41 & 117,3659 & 13,5936 \\
\hline
\end{tabular}

Of adolescent basketball players in our study, the mean age was $13.07 \pm 0.81$ years, the mean athletic age was $32.60 \pm 16.94$ months and the mean weekly training frequency $2.82 \pm 0.67$ days. Of the participants, the mean height was $158.10 \pm 11.75 \mathrm{~cm}$ and the mean weight was $55.47 \pm 14.53 \mathrm{~kg}$. From biyomotoric features, the mean vertical jump was $32.09 \pm 8.92 \mathrm{~cm}$, the mean time for running a mile was $7.73 \pm 1.66$ minute, the mean value of anaerobic power was $70.67 \pm 18.81 \mathrm{~kg} . \mathrm{m} / \mathrm{sec}$ and the mean value of aerobic power was $51.34 \pm 5.39$ $\mathrm{ml} / \mathrm{kg} / \mathrm{min}$. In somatotype assessment of adolescent basketball players in our study, the mean value of endomorphy was $4.60 \pm 2.15$, the mean value of mesomorphy was $4.57 \pm 1.47$ and the mean value of ectomorphy was $2.23 \pm 1.59$. The mean value of the Harrison basketball test that we aimed to identify the basketball-specific skills of the participants was $117.36 \pm 13.59$ points (Table 1.) 
The Effect of Somatotype Profiles of Adolescent Basketball Players on Biomotoric Characteristics ..

Table 2. The Relationship Between Somatotype Components of Adolescent Basketball Players and Biomotorical Features and Ability

\begin{tabular}{|c|c|c|c|c|}
\hline \multirow[t]{2}{*}{ Somatotype profile } & \multicolumn{4}{|l|}{ Variables } \\
\hline & & $\mathbf{n}$ & $\mathbf{r}$ & $\mathbf{p}$ \\
\hline \multirow{9}{*}{ Endomorphy } & Athletic age (month) & 41 & 0.205 & 0.200 \\
\hline & Weekly average training (day) & 41 & -0.040 & 0.806 \\
\hline & The body lenght $(\mathrm{cm})$ & 41 & 0.132 & 0.813 \\
\hline & The body weight $(\mathrm{kg})$ & 41 & 0.575 & $0.000 *$ \\
\hline & Vertical jump (cm) & 41 & -0.660 & $0.000 *$ \\
\hline & 1 mile run-walk (min) & 41 & 0.720 & $0.000 *$ \\
\hline & Anaerobic power (kg.m/sec) & 41 & 0.204 & 0.204 \\
\hline & Aerobic power $(\mathrm{ml} / \mathrm{kg} / \mathrm{min})$ & 41 & -0.735 & $0.000 *$ \\
\hline & Harrisson basketball test (score) & 41 & -0.374 & 0.016 \\
\hline \multirow[t]{9}{*}{ Mesomorphy } & Athletic age (month) & 41 & 0.038 & 0.815 \\
\hline & Weekly average training (day) & 41 & -0.287 & 0.069 \\
\hline & The body lenght $(\mathrm{cm})$ & 41 & -0.199 & 0.212 \\
\hline & The body weight $(\mathrm{kg})$ & 41 & 0.466 & 0.002 \\
\hline & Vertical jump (cm) & 41 & -0.273 & 0.085 \\
\hline & 1 mile run-walk (min) & 41 & 0.618 & 0.000 \\
\hline & Anaerobic power (kg.m/sec) & 41 & 0.294 & 0.062 \\
\hline & Aerobic power $(\mathrm{ml} / \mathrm{kg} / \mathrm{min})$ & 41 & -0.637 & 0.000 \\
\hline & Harrisson basketball test (score) & 41 & -0.463 & 0.002 \\
\hline \multirow[t]{9}{*}{ Ectomorphy } & Athletic age (month) & 41 & -0.036 & 0.825 \\
\hline & Weekly average training (day) & 41 & 0.223 & 0.161 \\
\hline & The body lenght $(\mathrm{cm})$ & 41 & 0.192 & 0.229 \\
\hline & The body weight (kg) & 41 & -0.509 & 0.451 \\
\hline & Vertical jump $(\mathrm{cm})$ & 41 & -0.451 & 0.003 \\
\hline & 1 mile run-walk (min) & 41 & -0.646 & 0.000 \\
\hline & Anaerobic power (kg.m/sec) & 41 & -0.249 & 0.116 \\
\hline & Aerobic power (ml/kg/min) & 41 & 0.677 & 0.000 \\
\hline & Harrisson basketball test (score) & 41 & 0.434 & 0.005 \\
\hline
\end{tabular}

The relationship between somatotype components and biyomotoric features and basketball specific skills was examined in Table 2. According to this analysis, there was a positive relationship between endomorphy value and body weight and time for running a mile and there was a negative relationship between endomorphy value and vertical jump distance aerobic power value and Harrison basketball test score. While there was a positive relationship between mesomorphy value and body weight and time for running a mile, there was a negative relationship between mesomorphy value and aerobic power value and Harrison basketball test score. While there was a negative relationship between ectomorphy value and vertical jump distance and time for running a mile, there was a positive relationship between ectomorphy value and aerobic power value and Harrison basketball test score.

\section{Discussion}

It is stated that anthropometry affects performance and has a relationship with the other criteria that affect performance (Cicchella et al., 2009). In the past studies, it has been demonstrated that the structural features of the body showed differences between different sports branches and between different categories of the same sports branches. The obtained data play an important role in directing athletes to sports branches, the training of small athletes and of elite athletes and increasing their performance. Therefore, it is very important to determine the morphological and physiological structures of the athletes (Carter and Heath, 1990; Heyward and Stolarczyk, 1996; Ross and Marfell-Jones, 1991; Zorba and Ziyagil, 1995)

Somatotype values of basketball players aged 12-14 years participating in our study were determined as (4.6-4.6-2.2). The definition of somatotype profile can be expressed as mesomorphy and endomorphy. In a study on Turkish Basketball Men's Junior National Team (U15), as a result of anthropometric measurements used in the somatotype assessment of basketball players, endomorphy value was 3, mesomorphy value was 4.1 and ectomorphy value was 3.6. The definition of Somatotype profile was specified as ectomorphic-mesomorphy (Ayan and Erol, 2016). In the study of Zorba et al. (1996), somatotype values of 36 basketball players aged 1215 years were determined as (1.7-5.2-3.4). In the study conducted on athletes in various sports branches by Mathur et al. (1985), somatotype values of basketball players were determined as (1.9-5.3-3.4). The findings obtained from these studies are not parallel to the findings of our study.

The somatotype values of the adolescent basketball players in our study were different from the values obtained in other studies. There can be many causes and especially it is thought that the age, eating habits, and frequency, intensity and quality of training are more prominent in the formation of these differences. 
The Effect of Somatotype Profiles of Adolescent Basketball Players on Biomotoric Characteristics ..

In our study, there was a moderate positive relationship between endomorphy value and body weight and there was a high positive relationship between endomorphy value and time for running a mile. There was a moderate negative relationship between endomorphy value and vertical jump distance and there was a high negative relationship between endomorphy value and aerobic power value and there was a weak negative relationship between endomorphy value and Harrison basketball test score. While there was a moderate positive relationship between mesomorphy value and body weight and time for running a mile, there was a moderate negative relationship between mesomorphy value and aerobic power value and Harrison basketball test score. While there was a moderate negative relationship between ectomorphy value and vertical jump distance and time for running a mile, there was a moderate positive relationship between ectomorphy value and aerobic power value and Harrison basketball test score. In the study where Ayan and Erol (2016) evaluated the relationship between their somatotype features and their performances in Turkish Basketball Men's Junior National Team (U15), while there was a weak negative relationship between endomorphy value and vertical jump and standing long jump, there was a weak positive relationship between endomorphy value and 20 meters sprint speed. While there was a weak positive relationship between mesomorphy value and vertical jump and standing long jump, there was a weak negative relationship between mesomorphy value and 20 meters sprint speed. While there was a weak positive relationship between ectomorphy value and vertical jump and 20 meters sprint speed, there was a weak negative relationship between ectomorphy value and standing long jump.

When Voisard (1954) examined the relationship between somatotype and performance in 10-13 year old boys, it was found that endomorphy affected performance negatively but ectomorphy affected positively. Mesomorphy was not related to performance. In the study made on male children between 9-12 years by Clarke (1971), it was found that there was a weak-to-moderate relationship between endomorphy and mesomorphy and force and there was a weak-to-moderate negative relationship between ectomorphy and force. In Raudsepp and Jurimae (1996), study the relationship between somatotype and physical fitness were not significant. Generally, endomorphy has low negative and mesomorphy positive relationships with physical fitness tests, whereas ectomorphy correlates significantly with physical fitness measures. Physical fitness elements had low positive correlation with mesomorphy and low negative correlation with endomorphy. The negative association between physical fitness and endomorphy was obvious especially in the activities requiring the whole body movement. Ectomorphy had no or slight correlation with physical fitness scores.

Consequently, we found that there was an increase in aerobic power values and basketball-specific skill points of the adolescent basketball players with prominent ectomorph features in our study. We consider that the determination of anthropometric and somatotype values of this age group in particular contributes to basketball talent search programme and that more detailed information on the topic will have been reached by implementing similar studies in athletes struggling at different ages and in various sports branches.

\section{References}

[1]. Ayan, V., Erol, A. E. (2016). Türk yıldız milli erkek basketbol takım sporcularının somatotip yapılarının ve performans özelliklerinin incelenmesi. Kastamonu Ĕ̆itim Dergisi, 24 (4), 2089-2098.

[2]. Carter, J.E.L., Heath, B.H. (1990). Somatotyping - development and applications. Cambridge University Press.

[3]. Cicchella A., Jidong L., Jürimäe T., Zini M., Passariello C., Rizzo L., Stefanelli C. (2009). Nthropometrıc comparıson between young estonian and chinese swimmers. Journal of Human Sport and Exercise, 4(2), 154-160.

[4]. Clarke, H. H. (1971). Physical and motor tests in the metford boys growt study. New Jersey: Prentice Hall.

[5]. Ersöz, G., Koz. M., Sunay. H., Gündüz, N. (1996) Erkek voleybol oyuncularının sezon öncesi, sezon ortası ve sezon sonu fiziksel uygunluk düzeyi parametrelerindeki değişmeler. Gazi Üniversitesi Beden Eğitimi ve Spor Bilimleri Dergisi, 1(4), 1-7.

[6]. Fox, E. L., Bowers, R. W., Foss, M. L. (2012). Çev: Mesut Cerit. Beden Eğitimi ve Sporun Fizyolojik Temelleri. Ankara: Spor Yayınevi.

[7]. George, J. D., Vehrs, P. R., Allsen, P. E., Fellingham, G. W., Fisher, A. G. (1993). VO2max estimation from a submaximal 1-mile track jog for fit college-age individuals. Medicine and Science in Sports and Exercise, 25, 401-406.

[8]. Gökdemir, K., Cicioğlu, İ., Günay, M. (1999) Farklı branşlardaki erkek sporcuların fiziksel ve fizyolojik özelliklerinin karșılaștırılması. Selçuk Üniversitesi Beden Eğitimi ve Spor Bilimleri Dergisi, 1(1), 16-21.

[9]. Gürses, Ç., Olgun, P. (1978) Sportif yetenek araştırma metodu (Türkiye uygulaması). İstanbul: Türk Spor Vakfi Yayını

[10]. Heimer, S., Misigoj, M., Medved, V. (1988). Some anthropological of top volleyball players in SFR Yugoslavia. The Journal of Sports Medicine Fitness, 28, 200-208.

[11]. Heyward, V.H., Stolarczyk, L. M. (1996). Applied body composition assessment. USA: Human Kinetics.

[12]. Hopper, D.M. (1997). Somatotype in high performance female netball players may influence player position and the incidence of lower limb and back injuries. British Journal of Sports Medicine, 31 (3), 197-199.

[13]. Kamar, A. (2008). Sporda yetenek beceri ve performans testleri. Ankara: Nobel Yayıncilık.

[14]. Kılıç, F., Günay, M., Gökdemir, K. (2000). Ümit milli bayan basketbolcularının bazı fizyolojik, biyomotorik özellikleri ve postür yapılarının incelenmesi. 1. Gazi Beden Ë̆itimi ve Spor Kongresi, Mayıs, Ankara.

[15]. Koz, M. (t.y.). Vücut kompozisyonu ve sportif performans ile ilişkisi. http://80.251.40.59/sports.ankara.edu.tr/koz/egzfizII/vucut.kompz.egz.pdf sayfasından erişilmiştir.

[16]. Mathur D. N., Torila A. L., Igbokwe N. V. (1985). Somototypes of nigerian athlets of several sports. British Journal of Sports Medicine, 19(4), 219-220.

[17]. Muratlı, S. (1997). Çocuk ve spor. Ankara: Bağırgan Yayınevi.

[18]. Özer, M. K. (2009). Kinantropometri sporda morfolojik planlama (2.Basım). Ankara: Nobel Basımevi.

[19]. Özer, M. K. (2015). Fiziksel uygunluk (5.Basim). Ankara: Nobel Yayıncılik.

[20]. Raudsepp, L., Jurimae, T. (1996). Somatotype and physical fitness of prepubertal children. Coll.Antropol, 20 (1), 53-59.

DOI: 10.9790/6737-04016166 www.iosrjournals.org 65 | Page


[21]. Ross, W. D., Marfell-Jones, M. J. (1991). Physiological Testing of the High-Performance Athlete. (MacDougall D. J., Wenger A. H., Green H. J, Ed.), Kinanthropometry , pp. 223-308. Illinois: Human Kinetics Books Champain.

[22]. Tamer, K. (2000). Sporda fiziksel-fizyolojik performansın ölçülmesi ve değerlendirilmesi. Ankara: Bă̆ırgan Yayınevi.

[23]. Voisard, P. P. (1954). A Study of the Relationship Between Body Build and Motor Educability of Elementary School Boys Ages 10-13. Unpublished Master Thesis. The University of Illinois.

[24]. Zorba, E., Kalkavan, A., Ağaoğlu, S., Karakuş, S. ve Çolak, H. (1996). Farklı spor branşlarında bazı fiziksel uygunluk değerlerinin sedanter grupla karșılaștırılması. G. Ü. Beden Eğitimi ve Spor Bilimleri Dergisi, 1(3), 25- 35.

[25]. Zorba, E., Ziyagil, M. A. (1995). Beden eğitimi ve spor bilimcileri için vücut kompozisyonu ve ölçüm metotları. Ankara: Gen Matbaacilik. 